\title{
GUIDED INQUIRY LEARNING-BASED BLENDED LEARNING ON CHEMICAL EQUILIBRIUM MATERIAL TO IMPROVE SENIOR HIGH SCHOOL STUDENT LEARNING OUTCOMES
}

\author{
Diyah Ayu Murti Ningsih* and Dian Novita \\ Chemistry Education Study Program, Faculty Mathematics and Natural Science, State University of Surabaya, \\ Surabaya, Indonesia \\ *Email: diyah.18001@mhs.unesa.ac.id
}

\author{
Accepted: January 02, 2022. Approved: January 14, 2022. Published: January 15, 2022
}

\begin{abstract}
This research aimed to improve student's learning outcomes on chemical equilibrium material through the application of guided inquiry learning used blended learning to determine students' activities and student responses for applied learning. This study uses observation and test methods to collect data and One Group Pretest-Posttest Design to determine an increase in student learning outcomes. The research was conducted at SMA Al-Islam Krian for the 2021/2022 academic year. The results showed that implementation of guided inquiry learning based on blended learning was $98.8 \%$, with a very good category. The percentage of student activity is $96 \%$. The learning outcomes obtained by the students showed an increase between the pretest and the posttest, with an average n-gain value of 0.8 in the high category, and from results of paired sample ttest was obtained by the Sig. (2-tailed) $0.000<0.005$, which means that there is a significant difference. The results of student responses during learning are $96 \%$. This research concludes that guided inquiry learning can improve students' learning outcomes on chemical equilibrium materials.
\end{abstract}

Keywords: Guided Inquiry, Student Learning Outcomes, Blended Learning, Chemical Equilibrium

\section{INTRODUCTION}

There is a minimum completeness criterion $(\mathrm{KKM})$ as a learning completeness criterion which refers to the graduation competency standard, where one aspect of the assessment is knowledge competence. According to Sutarno and Mukhidin (2013) explained that student success in learning can be seen from the results of the reviewed values regarding minimum completeness criterion [1]. Student learning outcomes can determine students' level of understanding and ability after following the learning process, which is then assessed and measured in the form of nominal numbers [2].

Several schools' student chemistry learning outcomes are still low, far from the minimum completeness criteria [3], such as at SMA Al-Islam Krian. The results of the pre-research obtained student's chemistry learning outcomes in the realm of knowledge (cognitive) chemical equilibrium material are still lower than the specified KKM of 75. The low value of student learning outcomes is because the teacher provides learning or selects an ensuite method used [4]. Based on the results of interviews, it was found that teachers tend to use the lecture method in providing learning in the classroom. Another factor affecting the low value of students learning outcomes is the lack of student interest in chemistry. Students think that learning chemistry is difficult to understand. It is supported by the results of pre-research in class XII MIPA 3 SMA Al-Islam Krian, where $70 \%$ of students think that chemistry learning is difficult to understand. It is caused due to the number of words that are difficult to understand and many formulas used so that students more often memorize than understand the formula [5].
Based on the pre-study above, we need a learning model for the student center. The teachers only act as facilitators to actively expand their new knowledge [6]. In the current era of globalization, it is very demanding to increase students' knowledge. Students' potential for the breadth of their knowledge will be very beneficial in competition in today's $21^{\text {st }}$-century education. [7].

The current curriculum development, namely the 2013 curriculum, also demands studentoriented learning, where students are placed as learning subjects. Student-oriented learning will produce learning outcomes equally in cognitive, affective, and psychomotor aspects. Studentoriented learning is guided inquiry. The inquiry learning models are learning activities that emphasize the thinking process in understanding natural phenomena and finding their learning concepts [8]. According to Wahyudi and Supardi (2013), guided inquiry learning is a learning model that can help learners learn and gain insight into knowledge in their way [9]. It is following the statement of Asmi (2020), states with guided inquiry, students can be more active in carrying out learning activities to improve scientific attitude skills and student learning outcomes[10].

Inquiry learning combined with blended learning is a mix of offline and online learning that can help students thrive in the 21st century[11]. Blended learning can produce active, creative, more in-depth, and student-centered learning and, more interesting, improve student achievement[12]. The application of guided inquiry can increase students' opportunities to improve analytical skills and thinking skills [13]. 
Guided inquiry learning is also very suitable to be applied in chemistry learning. Students are taught to find their concepts to become meaningful learners [14]. The research conducted, students' learning outcomes were improved at the cognitive levels of C3 (Application), C4 (Analysis), and C5 (Evaluation).

Based on the description above, it is hoped that inquiry learning using blended learning can improve student learning outcomes in chemical equilibrium material. Therefore it needs to be done "Guided inquiry learning-based blended learning on chemical equilibrium material improve students' learning outcomes for class XI Senior High School."

\section{RESEARCH METHOD}

This research uses quantitative descriptive analysis, which describes accurate, factual, and systematic variables [15]. The research was conducted at SMA Al-Islam Krian. The targets of research are class XI MIPA 3 SMA Al-Islam Krian. Data collection techniques were carried out using observation, tests, and questionnaires.

The design used in this research is one group pretest-posttest, namely the technique used to determine the difference before and after being given treatment. The design of one group pretest and posttest can be described as follows:

\begin{tabular}{|ccc|}
\hline Pretest & Treatment & Postest \\
$\mathrm{O}_{1}$ & $\mathrm{X}$ & $\mathrm{O}_{2}$ \\
\hline
\end{tabular}

Description :

$\mathrm{O}_{1}=$ Student learning outcomes before being given learning

$\mathrm{X}=$ Given learning

$\mathrm{O}_{2}=$ student learning outcomes after being given learning.

The analysis of the data obtained is an analysis of implementation learning, student activities, learning outcomes in the cognitive domain of students, analysis of students' cognitive levels (C3, C4, C5), and analysis of student responses.

Implementation of guided inquiry learning and student activities were analyzed using the learning implementation sheet and student activity observation sheet. The data obtained is then converted, which refers to table 1 below.

Table 1. Criteria for Learning Implementation

\begin{tabular}{ccc}
\hline No & Range & Criteria \\
\hline 1 & $0 \%-20 \%$ & Not Good \\
2 & $21 \%-40 \%$ & Not enough \\
3 & $41 \%-60 \%$ & enough \\
4 & $61 \%-80 \%$ & good \\
5 & $81 \%-100 \%$ & Very Good \\
\hline
\end{tabular}

The implementation of learning can be effective if it is at a percentage of $61 \%$ by getting good and very good categories.

Student learning outcomes were analyzed one group pretest-posttest. The results pretest and posttest then calculated the value of n-gain to know the improvement of student learning outcomes. The formula used:

$$
n-\text { gain }=\frac{\text { skor postest }- \text { skor pretest }}{\text { skor maksimal }- \text { skor pretest }}
$$

Furthermore, the results of n-gain values are grouped according to table 2 below:

Table 2. Criteria for Gain Value

\begin{tabular}{|c|c|c|}
\hline No & Value Range & Category \\
\hline 1 & $\mathrm{G} \geq 0,7$ & High \\
\hline 2 & $0,3 \leq \mathrm{G}<0,7$ & Medium \\
\hline 3 & $\mathrm{G}<0,3$ & Low \\
\hline
\end{tabular}

Besides being analyzed by calculating the value of gain value, student learning outcomes were also analyzed statistically with test normality and t-test to find out the difference in the value of the pretestposttest. T-test refers to the provisions hypothesis by statistics, namely:

$\mathrm{H}_{\mathrm{o}}=$ no significant difference between the pretest and posttest realm knowledge

$\mathrm{H}_{1}=$ no significant difference between the pretest and posttest realm of knowledge

As for guidance in making decisions on statistical analysis, this :

1. If the value Sig. (2-tailed) $<0.005$, then the hypothesis $\left(\mathrm{H}_{\mathrm{o}}\right)$ is accepted, and the hypothesis $\left(\mathrm{H}_{1}\right)$ is rejected.

2. If the value Sig. (2-tailed) $>0.005$, then the hypothesis $\left(\mathrm{H}_{\mathrm{o}}\right)$ is rejected, and the hypothesis $\left(\mathrm{H}_{1}\right)$ is accepted.

Student responses to the given learning were analyzed using student response questionnaires. The response results obtained are then analyzed about Guttman's scale criteria, according to Table 3 below:

Table 3. Guttman's scale criteria

\begin{tabular}{cc}
\hline Answer & Score \\
\hline Yes & 1 \\
No & 0 \\
\hline
\end{tabular}

\section{RESULT AND DISCUSSION}

Guided inquiry learning can improve student learning outcomes on chemical equilibrium material in class XI MIPA 3 SMA Al-Islam Krian. This research includes implementation of guided inquiry learning, student activities, students' learning outcomes in the cognitive domain, and student responses questionnaires. 


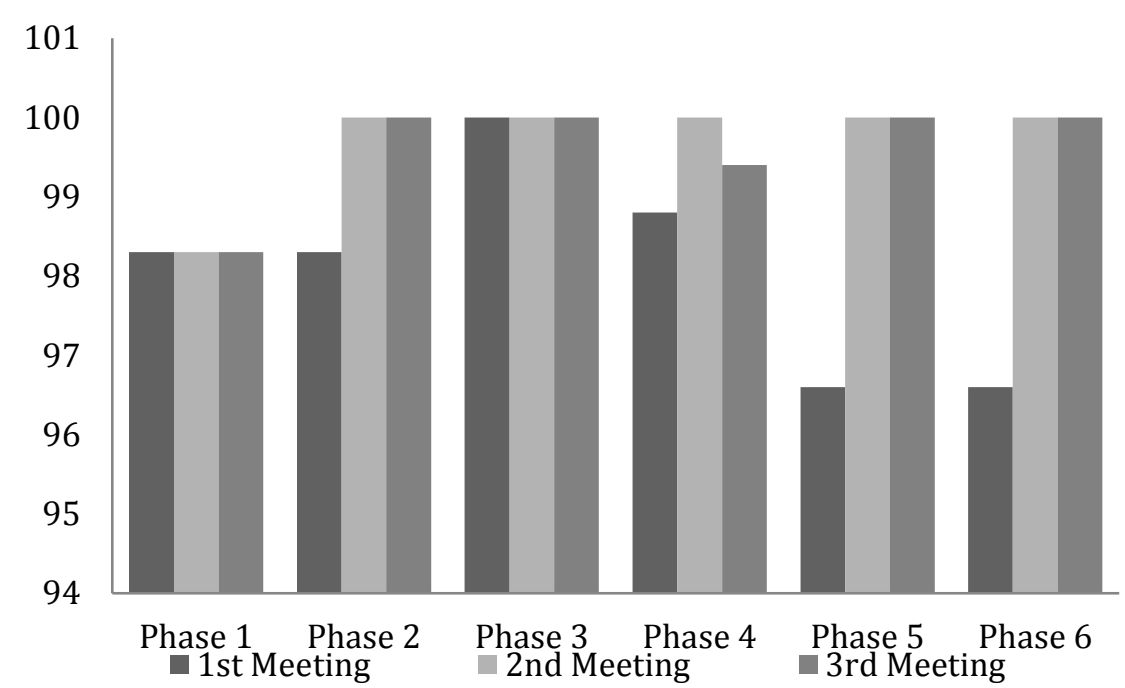

Figure 1. Graph of percentage implementation of the guided inquiry learning.

\section{Implementation of the Guided Inquiry Learning}

The purpose of observation is to discover the learning process provided by educators by applying a guided inquiry model following syntax. Three observers carried out this observation by filling out the provided learning implementation sheet-the results of the implementation of guided inquiry learning according to Figure 1.

This research was in 3 meetings; there were 6 phases of guided inquiry-based on blended learning at each meeting. As for the syntax of guided inquiry learning, (1) focusing students' attention; (2) Presenting a phenomenon; (3) helping students formulate hypotheses to explain phenomena; (4) encouraging students to collect data; (5) formulating and conclusions; (6) reflect on problem situations and thought processes. [17]

According to Harding, Kaczynski, and Wood (2005), Blended learning is a learning approach that integrates traditional offline learning and distance learning that uses online learning resources (especially web-based) and a variety of communication options that educators and students [18] can use.

Based on the graph of the implementation of guided inquiry learning in Figure 1, quality guided inquiry learning applied at each stage is in very good criteria. The average percentage of implementation at each meeting is $98.8 \%$. Following Riduwan's (2015) statements states that learning is said to be effective if the percentage of learning implementation is $61 \%$ in good and very good categories.

\section{Student Activities}

- Analysis of student activities was carried out using student activity observation sheets which were observed by three observers every 3 minutes of student activity. This analysis aims to analyze student activity and observe student behavior during the learning process. The results obtained can be used as a benchmark for learning in the classroom.

According to Riduwan (2015), student activity is categorized as good if relevant student activities are $61 \%$. The results of observed student activities are according to Figure 2.

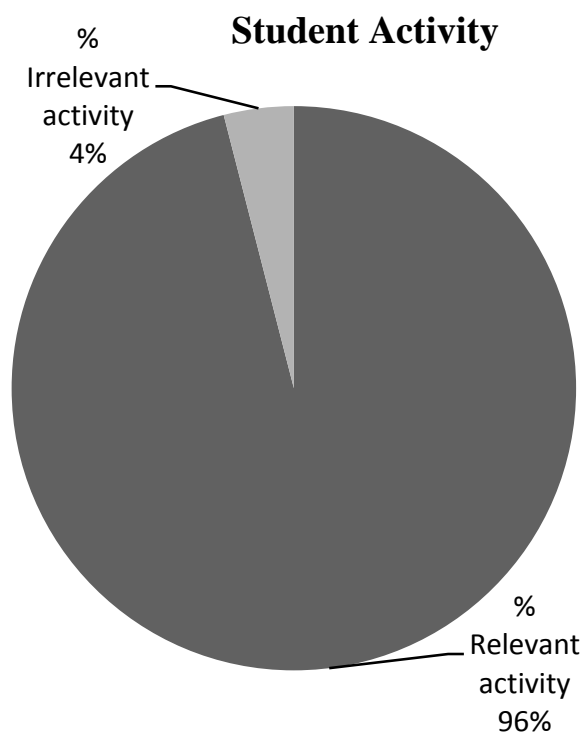

Figure 2. Graph of student activity

The graph of student activity in Figure 2 shows that the percentage of relevant student activities is greater than the percentage of irrelevant activities. It means students can take part in blended learning to be more active and innovative in the learning process. This description follows the opinion Sahni (2019), which states that blended learning is very useful because it is innovative, active, student- 
centered, and interesting to improve student's learning outcomes.

\section{Student Learning Outcomes in the Cognitive Area}

Analyzing students' learning outcomes in the cognitive domain aims to determine student learning outcomes in chemical equilibrium material before-after learning is given. Analysis was carried out by calculating the value of Gain to see the increase in student learning outcomes-the following table data on the results of increasing students' gain values.

Table 4. Value the n-gain of students on the ability of the realm of knowledge

\begin{tabular}{cc}
\hline Total of student & Criteria \\
\hline 8 & Medium \\
26 & High \\
\hline
\end{tabular}

The pretest and posttest questions given are in the form of multiple-choice and essay, cognitive levels ranging from $\mathrm{C} 3-\mathrm{C} 5$ levels, meaning that they range from the cognitive level to the application level to the evaluation level.

Students' cognitive abilities are categorized as good because the n-gain value obtained is medium and high. For the results of students' learning outcomes, completeness can be complete. The average students' learning outcome after being given learning is 86.32 . It means that the average value obtained is 75 so that overall XI MIPA 3 students are said to be complete in learning outcomes of chemical equilibrium material.

In addition to being tested by calculating the Gain value, the analysis of student learning outcomes in the cognitive domain was also calculated statistically using a statistical test paired sample t-test to know the difference between the average pretest scores and posttest. Before the ttest, a normality test was conducted to determine that the data used were normally distributed. From results of paired sample t-test were obtained by the Sig. (2-tailed) $0.000<0.005$, which means that there are significant differences between the pretest and posttest, so $\mathrm{H}_{\mathrm{o}}$ accepted

The T-test value of pretest and posttest are presented in Table 5.

Table 5. Result of Paired Sample t-Test

\begin{tabular}{llcrr}
\hline & & $\mathrm{t}$ & df & Sig. (2-tailed) \\
\hline Pair 1 & $\begin{array}{l}\text { Pretest - } \\
\text { Postest }\end{array}$ & $-32,813$ & 36 &, 000 \\
\hline
\end{tabular}

In addition to analyzing student learning outcomes as a whole, this study also analyzes student learning outcomes for each cognitive level, namely cognitive level C3 (Application), C4 (Analysis), and level C5 (Evaluation). The analysis was carried out by calculating the gain value from the pretest and posttest results at each cognitive level. The result data for gain value for each cognitive level is presented in Figure 3 below.

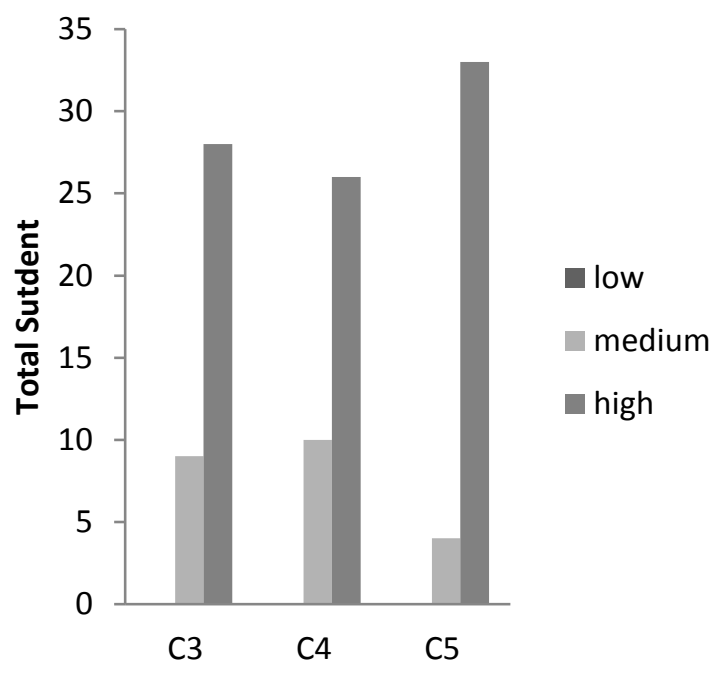

Figure 3. Results of the gain value at each cognitive level

Bloom's taxonomy is level groups thinking abilities from low (simple) to higher (complex) levels. According to Kreathwohl (2002:214), the bloom taxonomy in the cognitive domain includes C1 (remember), C2 (understand), C3 (apply), C4 (analysis), C5 (evaluation), and C6 (creativity) [19]. This study only used cognitive levels at C3 to C5. The cognitive level C3 (applying) is defined as applying or applying an experimental procedure or solving problems. Level C4 (analyzing) means breaking down the material in analyzing a problem. While the level of C5 (evaluating) means making decisions based on criteria or standards. Problems at level C5 are usually found in concluding the results of experiments or determining conclusions from the analysis of a problem.

Figure 3 shows that the results of gain value at each cognitive level are in the medium and high criteria. The average gain value is 0.8 , with a high category.

\section{Student Responses}

Analysis of student responses was carried out refers to the results of questionnaires that students have answered. The questionnaire given is in the form of a statement about the guided inquiry learning process used blended learning that has been given. The questionnaire was compiled based on the Guttman scale with yes and no answers. 
The results of this research from the student response questionnaire obtained $98.5 \%$ of students stated that learning with the guided inquiry model was very fun, more interesting, and better able to understand chemical equilibrium material. The scores obtained in the subsequent response questionnaires were averaged, and the percentage of student responses obtained was $96 \%$, with a very good category. It indicates that guided inquiry learning based on applied blended learning can increase students' positive responses. This statement follows the opinion of Riduwan (2015), which states that the results of student responses are said to be positive if the average percentage of responses obtained is $61 \%$

\section{CONCLUSION}

The conclusions drawn from this research are that the application of guided inquiry learningbased blended learning can improve students' learning outcomes in class XI MIPA 3 SMA AlIslam Krian. It can be seen that the increase in the n-gain values obtained for students of 0.8 in the high category, and there is a significant difference in the result of the pretest and posttest with the results of the paired sample t-test is $0,000<0.005$. The implementation of learning, observing student activities, and student responses were obtained in a very good category.

\section{REFERENCES}

[1] Sutarno, E., \& Mukhidin, M. (2013). Pengembangan Model Pembelajaran Berbasis Multimedia Interaktif Pengukuran untuk Meningkatkan hasil dan Kemandirian Belajar Siswa SMP di Kota Bandung. Jurnal Pendidikan Teknologi dan Kejuruan, 21(3).

[2] Siagian, R. E. F. (2015). Pengaruh minat dan kebiasaan belajar siswa terrhadap prestasi belajar matematika. Formatif: Jurnal Ilmiah Pendidikan MIPA, 2(2).

[3] Wardani, S, Firdaus. L. (2019). Pengaruh Model Inkuiri terbimbing Berbasis Blended Learning Terhadap Kemampuan KognitifPsikomotor Pada Materi Larutan Penyangga. Jurnal Tradis Kmiya,189-201.

[4] Munatri, S. (2016). Penerapan Model Pembelajaran Inkuiri Terbimbing untuk Meningkatkan Hasil Belajar Siswa pada Materi Sifat Koligatif Larutan di Kelas XI TKJ SMK Negeri 1 Buay Bahuga (Doctoral dissertation, UNIVERSITAS LAMPUNG).

[5] Aftriani. (2018). Pengaruh Pembelajaran Inkuiri Terbimbing Pada Pelajaran Kimia Terhadap Kemampuan Berpikir Kreatif Siswa Kelas XI IPA SMAN 2 MATARAM. Chemistry Educaion Practice. 1(2),2018-2

[6] Wahyuni, R., Hikmawati, H., \& Taufik, M. (2017). Pengaruh Model Pembelajaran Inkuiri Terbimbing dengan Metode Eksperimen terhadap Hasil Belajar Fisika Siswa Kelas XI IPA SMAN 2 Mataram Tahun Pelajaran 2016/2017. Jurnal Pendidikan Fisika dan Teknologi, 2(4), 164-169.

[7] Cucinotta, D., \& Vanelli, M. (2020). WHO declares COVID-19 a pandemic. Acta BioMedica: Atenei Parmensis, 91(1), 157-160.

[8] Crawford, B.A. s007. Learning To Teach Sciences as Inquiry in the Rough and Tumble of Practice. Journal of Research in Science Teaching. 44(4), 618-619.

[9] Wahyudi. L. E. \& Supardi. I. Z.A. (2013). Penerapan Model Pembelajaran Inkuiri Terbimbing pada Pokok Bhaasan Kalor untuk Melatihkan Keterampilan Proses Sains terhapa Hasil Belajar di SMAN 1 Sumenep. Jurnal Inovasi Fisika. 2(2), 62-65.

[10] Asni, A., Wildan, W., \& Hadisaputra, S. (2020). Pengaruh model pembelajaran inkuiri terbimbing terhadap hasil belajar kimia siswa materi pokok hidrokarbon. Chemistry Education Practice, 3(1), 17-22.

[11] Suana, dkk. (2017). Pengembangan Perangkat Blended Learning Berbasis Learning Management System (Lms) Dengan Model Pembelajaran Inkuiri Pada Materi Listrik Statis. Prosiding Seminar Nasional Pendidikan FKIP UNTIRTA. ISBN 978-60219411-2-6

[12] Sahni, J. (2019). Does Blended Learning Enhance Student Engagement? Evidence from Higher Education. Journal of $E$ Learning and Higher Education, 2019, 1-14.

[13] Sousa. C., (2016). Inquiry Learning for Gender Equity Using History of Science in Life and Earth Sciences Learning Environment. Journal for Education, Social and Technological Science Vol. 3.

[14] Sulastri. (2019). Pengaruh Penerapan Model Pembelajaran Inkuiri Terbimbing Berbantuan Lembar Kerja Siswa terhadap kemampuan Berpikir Kreatif Siswa Pada Materi Kolod. Proceding Biology Education Conforence. Vol 13(1), 335-344.

[15] Sugiyono. (2012). Metode Penelitian pendekatan Kuantitatif dan $R \& D$. Bandung:Alfabeta.

[16] Riduwan. (2015). Skala Pengukuran Variabel-variabel Penelitian. Bandung:Alfabeta

[17] Arends. R.I. (2013). Learning to Teach 9th ed. New York: Mc Graw Hill.

[18] Harding, A, Kaczynsky, D\&Wood, L.N. (2005). Evaluation of Blended Learning: Analysis of Quantitative Data, Universe Science Blended Learning Symposium proceedings., 56-72.

[19] Krathwohl, D. R. (2002). A Revision of Bloom's: An Overview. Theory into Practice, 44(4), 212-218. 
J. Pijar MIPA, Vol. 17 No.1, January 2022: 28-33

ISSN 1907-1744 (Print)

DOI: $10.29303 / j p m . v 17 i 1.3183$

ISSN 2460-1500 (Online)

[20] Anggraini. N, Suana, Sesunan. F. (2020).

Pengaruh Penerapan Blended Learning pada

Materi Hukum Newton tentang Gerak

Terhadap Motivasi belajar dan Kemampuan

Pemecahan Masalah. Jurnal Ilmu Pendidikan,

Vol. 16. No. 1, 22-36. 